\title{
Clinical study on the success of posterior monolithic zirconia crowns and fixed dental prostheses: preliminary report
}

\author{
Merve Bankoğlu Güngör, ${ }^{\text {* }}$ Seçil Karakoca Nemli, ${ }^{1}$ \\ Alper Çağlar, ${ }^{2}$ Cemal Aydın, ${ }^{1}$ Handan Yılmaz ${ }^{1}$ \\ ${ }^{1}$ Department of Prosthodontics, Faculty of Dentistry, Gazi \\ University, ${ }^{2}$ Department of Prosthodontics, Faculty of Den- \\ tistry, Başkent University, Ankara, Turkey
}

\begin{abstract}
ObJective: The purpose of this report was to present preliminary clinical results regarding the success rates and technical outcomes of posterior monolithic zirconia single tooth crowns (STs) and fixed dental prostheses (FDPs).

Materials and Method: Thirty-four patients received 43 posterior monolithic zirconia restorations as single tooth crowns (STs) and/or fixed dental prostheses (FDPs), which were fabricated using a CAD-CAM (Computer Aided Design - Computer Aided Manufacturing) system. At baseline and every 6 months, the restorations were examined for survival and technical outcomes. Success of the restorations was defined as the restoration remaining in situ, with no need for removal or replacement at followup visits. Technical outcomes were evaluated with a modified version of the United States Public Health Services criteria. Survival of restorations was estimated by using the Kaplan-Meier survival analysis. For each restoration, duration of follow-up was calculated from the time of placement to the date of its first failure.
\end{abstract}

RESULTS: After a mean observation period of $18.6 \pm 3.9$ months (between 8-24 months), cumulative survival rates were $\mathbf{8 6 . 7 \%}$ and $\mathbf{9 2 . 3} \%$ for STs and FDPs, respectively. Technical evaluation revealed good marginal adaptation and crown contours; however, modifications were needed for shade and occlusion of restorations.

Conclusion: These preliminary results revealed high survival rate and generally successful technical outcomes for posterior monolithic zirconia STs and FDPs.

Received: June 26, 2016; Accepted: January 21, 2017

*Corresponding author: Dr. Merve Bankoğlu Güngör, Department of

Prosthodontics, Faculty of Dentistry, Gazi University, Emek, Ankara, Turkey;

E-mail: mervebankoglu@yahoo.com
KEYwORDS: CAD-CAM; survival analysis; yttria stabilized tetragonal zirconia

Citatıon: Bankoğlu Güngör M, Karakoca Nemli S, Çağlar A, Aydın C, Yılmaz H. Clinical study on the success of posterior monolithic zirconia crowns and fixed dental prostheses: preliminary report. Acta Odontol Turc 2017;34(3):104-8

EdıToR: Güven Kayaoğlu, Gazi University, Ankara, Turkey

CopyriGHT: (c) 2017 Bankoğlu Güngör et al. This work is licensed under a Creative Commons Attribution License. Unrestricted use, distribution and reproduction in any medium is permitted provided the original author and source are credited.

\section{INTRODUCTION}

Zirconia-based ceramics which have superior mechanical properties are used as substructure material, veneered with glass ceramics because of its opacity. In clinical applications, chipping of the veneer is the most frequent complication, thereby reducing the success rate of zirconia fixed dental prostheses (FDPs). ${ }^{1,2}$ In order to overcome this problem, translucent or monolithic zirconia is needed, which enables the fabrication of monolithic restorations without veneering porcelain. Advantages of monolithic zirconia restorations include increased material quality with presintered homogeneous blocks used in the CAD-CAM (Computer Aided Design - Computer Aided Manufacturing) technique and a reduced production time/cost. In addition, permitting for material thickness of $0.5 \mathrm{~mm}$, due to high mechanical strength, contributes to the preservation of tooth substance and the use of all-ceramic restorations in case the interocclusal space is limited. ${ }^{3}$ However, information is lacking on clinical results of monolithic zirconia restorations. ${ }^{4,5}$ Few clinical studies focused on enamel wear caused by monolithic zirconia restorations. However, they reported comparable or lower antagonist enamel wear than that caused by other ceramic materials. ${ }^{4,5}$ The purpose of this report was to represent preliminary clinical results, including success rates, technical and esthetic evaluations of posterior monolithic zirconia crowns, and FDPs. 


\section{Materials and Method}

This study consisted of patients who received monolithic zirconia single tooth crowns (STs) and/or fixed dental prostheses (FDPs) supported by teeth at the Department of Prosthodontics, Faculty of Dentistry, Gazi University, Ankara, Turkey. The Ethics Committee of Ankara University approved the study (No. 36290600/21), with all participants providing informed consent for clinical procedures. Thirty-four patients were treated with 43 posterior monolithic restorations. The inclusion criteria consisted of having vital or adequately endodontically-treated abutment teeth and good general health, without severe medical or psychological conditions. Exclusion criteria were signs of bruxism, severe periodontal disease, and being less than 18 years old. All teeth were prepared according to a standardized protocol for zirconia-based restorations (Figure 1). ${ }^{1}$ In addition, all preparations were standardized: occlusal thickness of the restorations was at least $1.5 \mathrm{~mm}$ at the lowest point of the central fossa, and axial reduction was approximately $1-1.5 \mathrm{~mm}$. Also, $1 \mathrm{~mm}$ rounded shoulder margins and internal line angles were provided.

Digital impressions were taken by using an intraoral scanner (CEREC Omnicam, Sirona, Bensheim, Germany) by an experienced dentist. Restorations were designed using CAD software (InLab SW 4.2, Sirona). The connectors for FDPs were designed with a mini- mum of a $12 \mathrm{~mm}^{2}$ area. Restorations were milled from a partially-sintered translucent zirconia block, and colored by being dipped in a staining liquid (InCoris TZI, Sirona), then fully-sintered under the required conditions of the manufacturer. All restorations were checked for marginal fit, inter-proximal contact, and occlusion before cementation; they were steam cleaned, dried, glaze pasted (Ivoclar Vivadent, Schaan, Liechtenstein) and applied according to the manufacturer's recommendations. The restorations were cemented with adhesive resin cement (Panavia 21, Kuraray, Osaka, Japan). No pretreatment of the zirconia surface was done (Figure 2).

At baseline (within 2 weeks after cementation), and then every 6 months, the restorations were examined clinically and radiologically by two calibrated clinicians, who were not involved in the treatment. Success of the restorations was assessed and defined as the restorations remaining in situ, with no need for removal or replacement at follow-up visits. Technical outcomes were evaluated by a modified version of the United StatesPublic Health Services (USPHS) criteria. ${ }^{6}$

The longevity of restorations was estimated with the Kaplan-Meier survival analysis, using a software package (SPSS 18.0, SPSS Inc, Chicago, IL, USA). For each restoration, the duration of follow-up was calculated from the time of placement to the date of its first failure.

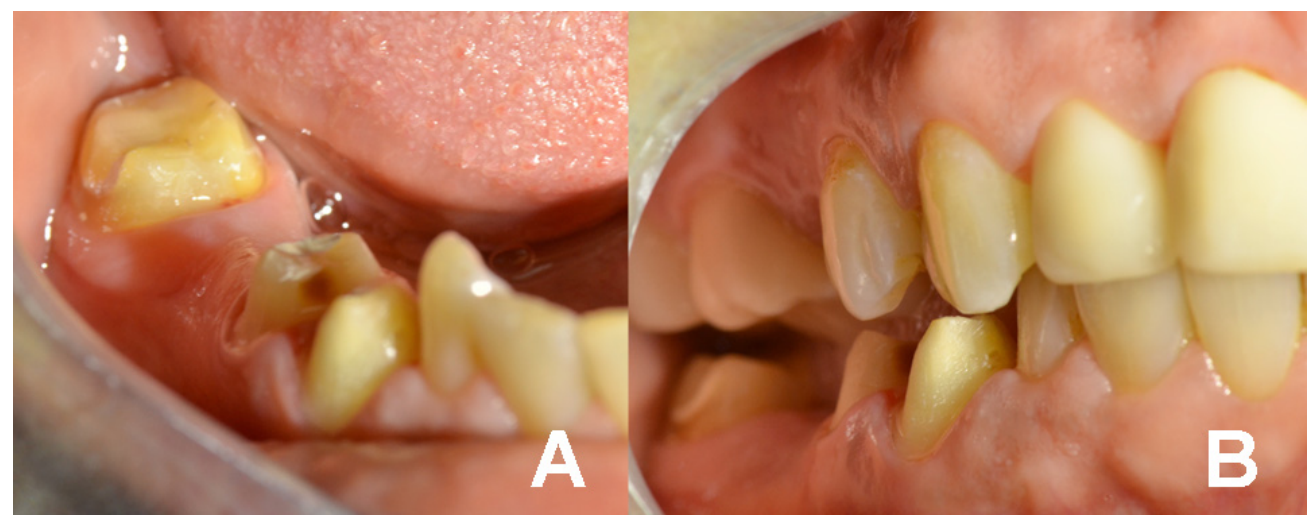

Figure 1. Intraoral view of the prepared teeth: $(A)$ buccal view of the tooth preparation, $(B)$ view of tooth preparation at maximum intercuspal position

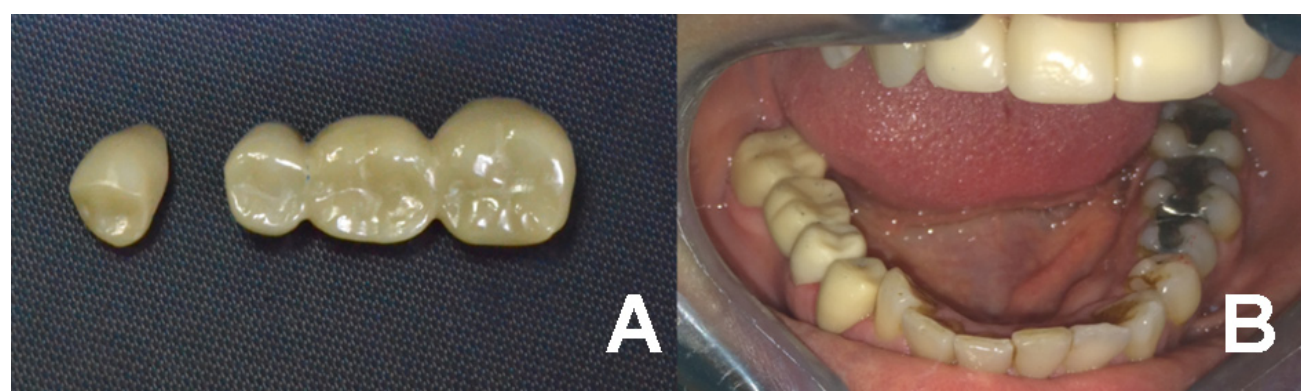

Figure 2. Photographs of single tooth crown and fixed dental prosthesis: $(A)$ polished restorations before cementation, (B) single tooth crown and fixed dental prosthesis in situ. 


\section{RESULTS}

Patient and restoration data are summarized in Table 1. After a mean observation period of $18.6 \pm 3.9$ months (between 8-24 months), all 43 restorations in 34 patients were examined. According to the Kaplan-Meier analysis, the success rates were $86.7 \%$ (26 surviving, 4 failures) and $92.3 \%$ (12 surviving, 1 failure) for STs and FDPs, respectively. The cumulative proportion of those surviving at 24 months (survival rates) was 0.612 (standard error: 0.197) for STs, and 0.923 (standard error: 0.74) for FDPs (Figure 3). Failures observed in the study are shown in Table 2. Restoration ratings according to the USPHS criteria are summarized in Figure 4.

Table 1. Summary of patient and restoration data

\begin{tabular}{ll}
\hline Age & $\begin{array}{l}\text { Mean: } 45.6( \pm 18.4) \text { years; } \\
\text { Range: } 20-63 \text { years }\end{array}$ \\
\hline Gender & 16 males, 18 females \\
\hline Restorations & $\begin{array}{l}\text { Total: } 43 \text { posterior restorations } \\
\text { Single tooth crown: } 30 \text { (18 molar, } 12 \text { premolar) }\end{array}$ \\
\hline Fixed dental prosthesis: 13
\end{tabular}

Table 2. Failure type, number of failures, and timing of failure after placement

\begin{tabular}{lcc}
\hline Failure type & $\begin{array}{c}\text { Number of } \\
\text { failures }\end{array}$ & $\begin{array}{c}\text { Timing of failure after } \\
\text { placement }\end{array}$ \\
\hline Crown fracture & 1 & 10 month \\
\hline Connector fracture & 1 & 8 month \\
$\begin{array}{l}\text { Decementation* } \\
\begin{array}{l}\text { Endodontic treatment } \\
\text { requirement }\end{array}\end{array}$ & 1 & 5 month \\
Unesthetic appearance & 2 & 13 month \\
\hline
\end{tabular}

${ }^{*}$ The restoration was recemented and accepted in surviving group

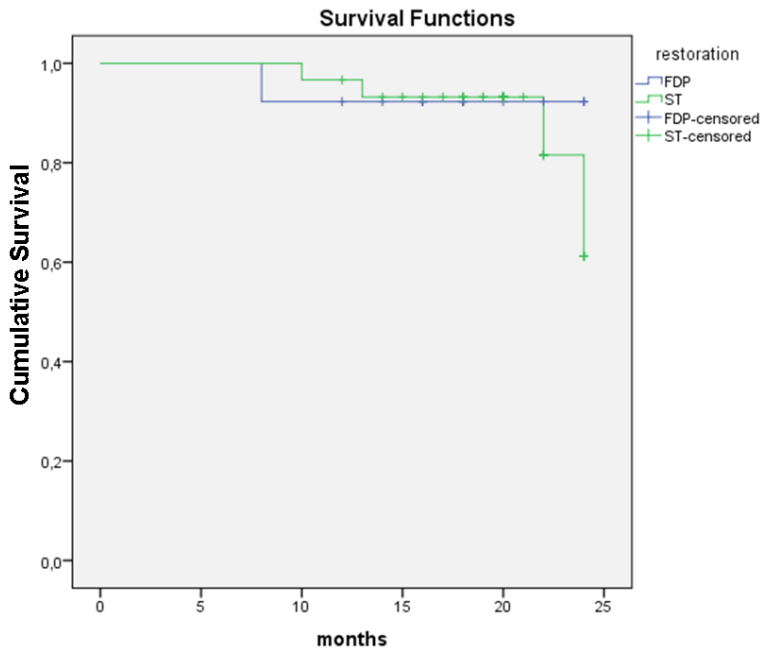

Figure 3. Kaplan-Meier analysis results. Cumulative proportion (vertical axis) surviving at the time (horizontal axis) is 0.612 (standard error: 0.197) for STs, and 0.923 (standard error: 0.74) for FDPs. [FDP: fixed dental prosthesis (failed); FDP-censored: fixed dental prosthesis- censored (survived); ST: single tooth crown (failed); ST-censored: single tooth crown-censored (survived)]

\section{Discussion}

In this preliminary report of an ongoing clinical study, high success rates (overall $88.4 \%$ ) were found for posterior monolithic zirconia restorations with up to 24 months of follow-up. In the literature, to the best of the authors' knowledge, no clinical study has reported on success rates of similar restorations. Analyzing failures revealed only two restorations fractured during function, while other failures resulted from biological or esthetic complications. Several in vitro studies reported very high fracture strength values for monolithic zirconia crowns, ranging from $1700 \mathrm{~N}$ to $6000 \mathrm{~N}$, even with chewing simulation. ${ }^{7-9}$ Considering the previous research, which reported an average posterior biting force of $700 \mathrm{~N},{ }^{10}$ fracture of monolithic zirconia restorations should not be expected. However, in vitro studies did not completely mimic the clinical situation. ${ }^{8}$

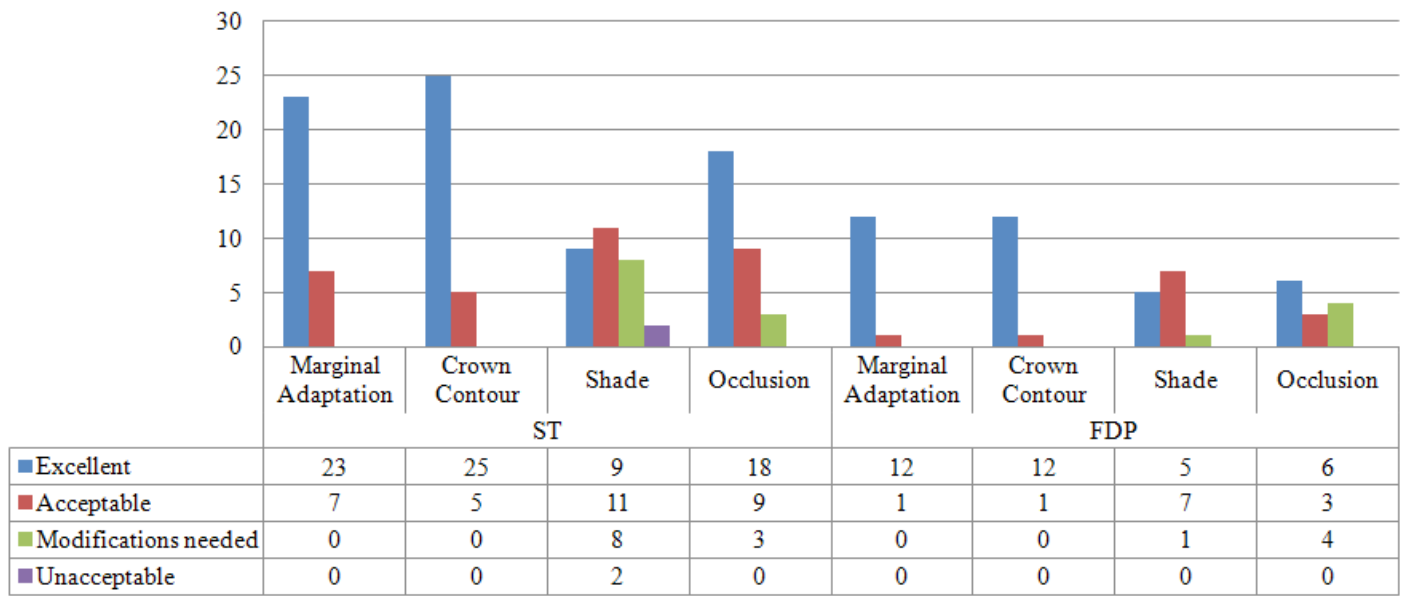

Figure 4. Restoration ratings according to the United States Public Health Services criteria (ST: single tooth crown; FDP: fixed dental prosthesis) 
Technical evaluation revealed that marginal adaptation rated as "excellent" or "acceptable" for STs and FDPs. Improved adaptation may be attributed to advanced CAD-CAM technology, including intraoral scanning and precise milling of industrially-sintered blocks. ${ }^{3}$ This is in agreement with the clinical findings of Batson et al. ${ }^{6}$ who reported good marginal adaptation of monolithic zirconia crowns.

Accurately reporting the patient's occlusion to the laboratory is a prerequisite for conventional prosthetic procedures, but the correct simulation of these contacts is also important for the CAD-CAM technique. Thus, restorations can be integrated into the stomatognathic system, and be biologically compatible, esthetically pleasant, and require less time for the insertion (without clinical adjustments). In this study, milled and sintered monolithic zirconia restorations, especially FDPs, required considerable occlusal adjustment when placed. This may be attributed to lack of accuracy of CAD software in simulating jaw occlusion, which includes posterior multiple teeth preparations. ${ }^{11}$ To minimize discrepancies, taking a full-arch digital impression and designing the restoration on full-arch virtual models, as well as gathering bite image impressions before preparation, has been strongly advocated by Arslan et al. ${ }^{11}$

The esthetic success of a dental restoration depends on a number of factors, such as crown contour, surface texture, translucency, and color. In the present study, crown contours were generally found to be "excellent". This might be attributed to individualizing the CAD software, which generated the virtual restoration design of an experienced clinician. However, problems were recorded about shade matching of the monolithic zirconia restorations with the remaining dentition. These translucent zirconia materials have been developed to improve light transmittance, and are therefore more translucent than conventional zirconia. On the other hand, they have significantly less translucency compared with conventional glass ceramics. ${ }^{12}$ Furthermore, translucency decreases with increasing monolithic zirconia thickness. ${ }^{13}$ Nevertheless, shade matching with the natural dentition may be challenging during clinical application. Further research is needed to enhance the translucency of zirconia.

Limitations of the present study include the absence of a control group for comparison with posterior monolithic zirconia restorations, short follow-up time, and small number of patients. The clinical performance of prosthetic reconstructions should be assessed by welldesigned, longitudinal (minimum of 5 years), randomized controlled clinical trials. ${ }^{1,3}$ Further clinical studies with longer follow-up and larger cohort size are needed for optimal monolithic zirconia restorations.

\section{Conclusion}

The preliminary results showed that monolithic zirconia single tooth crowns and fixed dental prostheses had high survival rates and generally successful technical outcomes.

Conflict of interest disclosure: The authors declare no conflict of interest related to this study.

\section{References}

1. Raigrodski AJ, Chiche GJ, Potiket N, Hochstedler JL, Mohamed $\mathrm{SE}$, Billiot S, et al. The efficacy of posterior three-unit zirconium-oxidebased ceramic fixed partial dental prostheses: a prospective clinical pilot study. J Prosthet Dent 2006;96:237-44.

2. Kavasoğlu M, Akçaboy C. Üst yapı porseleni uygulamasının yarı ve tam sinterize zirkonya alt yapıların bükülme dayanıklılıklarına etkisi. Acta Odontol Turc 2015;32:12-8.

3. Passia N, Stampf S, Strub JR. Five-year results of a prospective randomised controlled clinical trial of posterior computer-aided designcomputer-aided manufacturing $\mathrm{ZrSiO} 4$-ceramic crowns. J Oral Rehabil 2013;40:609-17.

4. Mundhe K, Jain V, Pruthi G, Shah N. Clinical study to evaluate the wear of natural enamel antagonist to zirconia and metal ceramic crowns. J Prosthet Dent 2015;114:358-63.

5. Stober T, Bermejo JL, Rammelsberg P, Schmitter M. Enamel wear caused by monolithic zirconia crowns after 6 months of clinical use. $J$ Oral Rehabil 2014;41:314-22.

6. Batson ER, Cooper LF, Duqum I, Mendonca G. Clinical outcomes of three different crown systems with CAD/CAM technology. J Prosthet Dent 2014;112:770-7.

7. Oilo M, Kvam K, Reisegg K, Gjerdet NR. The Effects of Margin Curvature on Load at Fracture of Ceramic Crowns. Int J Prosthodont 2015;28:357-9.

8. Johansson C, Kmet G, Rivera J, Larsson C, Vult Von Steyern P. Fracture strength of monolithic all-ceramic crowns made of high translucent yttrium oxide-stabilized zirconium dioxide compared to porcelain-veneered crowns and lithium disilicate crowns. Acta Odontol Scand 2014;72:145-53.

9. de Kok P, Kleverlaan CJ, de Jager N, Kuijs R, Feilzer AJ. Mechanical performance of implant-supported posterior crowns. J Prosthet Dent 2015;114:59-66

10. Ferrario VF, Sforza C, Zanotti G, Tartaglia GM. Maximal bite forces in healthy young adults as predicted by surface electromyography. $\mathrm{J}$ Dent 2004;32:451-7.

11. Arslan $Y$, Bankoglu Gungor M, Karakoca Nemli S, Kokdogan Boyaci B, Aydin C. Comparison of Maximum Intercuspal Contacts of Articulated Casts and Virtual Casts Requiring Posterior Fixed Partial Dentures. J Prosthodont 2016; doi:10.1111/jopr.12439.

12. Harianawala HH, Kheur MG, Apte SK, Kale BB, Sethi TS, Kheur SM. Comparative analysis of transmittance for different types of commercially available zirconia and lithium disilicate materials. J Adv Prosthodont 2014;6:456-61.

13. Sulaiman TA, Abdulmajeed AA, Donovan TE, Vallittu PK, Narhi TO, Lassila LV. The effect of staining and vacuum sintering on optical and mechanical properties of partially and fully stabilized monolithic zirconia. Dent Mater J 2015;34:605-10.

\section{Monolitik zirkonya kron ve köprülerin başarısı üzerine klinik çalışma: ön rapor}

\section{Özet}

AmAÇ: Bu çalışmanın amacı, posterior monolitik zirkonya tek kronlara ve köprülere ait klinik ön sonuçları sunmaktır.

Gereç Ve Yöntem: Otuzdört hastaya, Bilgisayar Destekli Tasarım - Bilgisayar Destekli Üretim (CAD-CAM) sistemi kul- 
lanılarak posterior bölgede toplam $\mathbf{4 3}$ monolitik zirkonya restorasyon (kron ve/veya köprü) yapıldı. Restorasyonlar, başlangıç aşamasında ve 6 ayda bir sağ kalım oranı ve teknik açısından değerlendirildi. Restorasyonların başarısı, takip süresince restorasyonların in situ olarak yerinde kalmasına veya uzaklaştırma veya yeniden yerleştirme ihtiyacına göre tanımlandı. Teknik değerlendirmeler modifiye Amerika Birleşik Devletleri Halk Sağlığı Kriterleri ile yapıldı. Bütün restorasyonların sağ kalımı, Kaplan-Meier sağkalım analizi kullanılarak değerlendirildi. Her bir restorasyonun takip süresi, restorasyonun yerleştirilmesinden ilk başarısızlık tarihine kadar olan süre olarak kabul edildi.
BULGULAR: Ortalama $18.6 \pm 3.9$ ay gözlem süresinde (8-24 ay aralığında), tek kronlara ve köprülere ait kümülatif sağkalım oranı sırasıyla \%86.7 ve \%92.3'tü. Teknik değerlendirmede, restorasyonların iyi marjinal adaptasyon ve kron konturu gösterdiği; ancak restorasyonların renk ve oklüzyon için düzenlemelere ihtiyaç duyduğu belirlendi.

Sonuç: Bu ön sonuçlar, posterior monolitik zirkonya tek kron ve köprülerin yüksek sağkalım oranı gösterdiğini ve genel olarak teknik açıdan başarılı olduklarını ortaya koymaktadır.

AnAhtar Kelimeler: CAD-CAM; sağkalım analizi; yttria stabilize dörtgen zirkon 